\title{
MIES AND SHIVA'S ECOFEMINISM: a new testament?
}

\author{
Maxine Molyneux and Deborah Lynn Steinberg'
}

\section{Introduction}

It is difficult to identify the boundaries of what constitutes ecofeminism as both a field of critical theory and as a politics. Ecofeminism is constituted by, and draws upon a diverse range of political and theoretical projects including environmental studies, critiques of science and modernity, development studies and a range of feminist critical writing and activism. Nevertheless, it can be argued that there are several common themes that run through most ecofeminist writing. These include: a critique of patriarchal science, a concern with the degradation of 'nature'/the environment and the making of links between these two and the oppression of women. The publication of Mies's and Shiva's Ecofeminism (1993) marks a notable attempt to bring together these diverse strands, including those themes common to most ecofeminist texts, which the authors consider to constitute a definitive basis on which an ecofeminist politics can be constructed.

Ecofeminism is a collection of twenty essays, some of which have been published elsewhere and most of which draw upon earlier work. The book has been widely reviewed, largely due to the international profile of its authors and their long history of engagement in feminist political debate. Maria Mies is perhaps best known for her book Patriarchy and Accumulation on a World Scale (1986); Vandana Shiva has received much acclaim for her book Staying Alive (1989). These earlier works clearly inform the multi-stranded agenda of Ecofeminism.

It is our view that Ecofeminism is an important collaboration at a number of levels. First, it represents an attempt to elaborate a dialogue between a Western feminist and 'Southern' feminist standpoint in which some differences and many commonalities emerge. Second, the themes of the book respond to the current and growing interest in how global or international processes are gendered. Third, the book embodies and 
extends the interdisciplinarity that constitutes the terrain of ecofeminism more generally. Here the authors make critical links among a number of areas of debate including: the violent, patriarchal character of Western scientific paradigms, their development within the project of colonialism and their part in environmental degradation, and the destructive character of capitalist development and the oppression of women. Specific chapters also deal with sex tourism, pornography, colonialism and nationalism within the broader remit of the book. Ecofeminism therefore marks a significant moment in feminist debates not only about environmental issues but also about a number of broader concerns within feminism as a whole. As such it provides an important reference point both for an assessment of the character of ecofeminist thought and politics and of the various fields which constitute it. To appreciate both the contribution of this work and the problematic questions it raises, it is necessary to examine in some detail its standpoint and key arguments. It is beyond the scope of this discussion to consider the enormous range of issues addressed in this collection. We will therefore focus our reflections on two key dimensions: its critique of science and of capitalist development in relation to the formulation of an ecofeminist standpoint and politics.

A core theme throughout Mies's and Shiva's Ecofeminism is a critique of modern science and Enlightenment thought. Indeed, it could be argued that Mies and Shiva's interrogation of scientific epistemologies and practices is a linchpin which grounds what they have to say about ecological degradation, development, the position of women and ecofeminist activism. Given the centrality of Mies's and Shiva's perspectives on science to the breadth of issues considered in the book, it is necessary to contextualize them with respect to the broader field of feminist critique of science.

\section{Feminist critiques of science and the enlightenment}

A critique of (at least some of) the underpinning assumptions of Western science has been a central, if not always explicit, element of much feminist political theory. ${ }^{2}$ Across disciplines, core elements of Enlightenment thought have been identified by feminists as underpinning the reproduction of fundamental social inequalities, particularly of gender. For example, feminists have questioned claims of objectivity, the notion and uses of the concept of rationality, the assumption of a universal subject, and the of knowledge from power (i.e., 'truth' from politics). At the same time, the 'science question in feminism' (Harding, 1986) has historically been a vexed one and a site of considerable debate. Thus some feminists, such as Lovibond (1989) have argued specifically for the value of Enlightenment epistemology, including the concept of rationality, as a necessary grounding for feminist theory, particularly in relation to the development of a materialist critique, and feminist politics. Ecofeminism has clearly emerged out of a long and diverse 
tradition of feminist critical engagement with these issues, particularly with respect to those strands which are more or less anti-Enlightenment. Mies and Shiva draw very eclectically (and selectively) on this body of critical literature, recasting as self-evident what have been highly contested approaches to the shared project of critique without, however, adequately identifying the origins of their own ideas. Thus, while it is clear that Mies and Shiva can be located broadly within a feminist critical tradition in relation to science, what is less clear is where more precisely they see themselves in relation to these debates.

In addition to the diversity characteristic of the project of developing critiques of scientific values, the relationship between feminism and science has also been characterized by a marked ambivalence about the emancipatory potential of science. Indeed, alongside the production of a critique of science, much of the history of feminism has also revolved around a pursuit and advocacy of scientific literacy ${ }^{3}$ and an investment in the potential of scientific enterprise to remedy the burdens of inequality endured by women. This ambivalence about the value of science can also be played out in epistemological terms, that is, in the ways in which feminist epistemologies can constitute both a critique of and a reproduction of scientific rationality simultaneously.

For example, within the context of feminist critiques of science, as Sandra Harding $(1986 ; 1991 ; 1992)$ has pointed out, there are divergent investments in the value of modern science. Harding argues that what she calls feminist empiricist critics have evaluated the relationship between science and women's oppression in terms of failures to adhere to the principles of scientific method - i.e., the problem is 'bad science'. Feminist standpoint theorists, on the other hand, have argued that it is what is considered to be 'good' science ('science-as-usual') which is oppressive to women. Thus, feminist standpoint theorists have critiqued feminist empiricists for their explicit investment in the principles of modern science, arguing that the use/abuse approach to the critique of science privileges science as a sphere outside politics and fundamental inequalities which are seen to shape every other social enterprise and institution. Feminist Standpoint theorists argue that science is both a political enterprise and constitutes an epistemology and set of practices which are intrinsically oppressive in gendered ways. Insofar as the critique of science embodies a critique of Enlightenment rationality, a feminist standpoint approach can be taken as fundamentally antiEnlightenment. However, it has been pointed out, explicitly by some feminists (e.g., Haraway 1989) that the feminist standpoint critique can be as contradictory in this respect as feminist empiricism though in somewhat different terms. While empiricists might state an explicit attachment to scientific rationality, standpoint theorists reproduce the essentialist and universalist assumptions about gender and power which are critiqued as the hallmarks of modern scientific thinking. ${ }^{4}$

It is in this context that the critique of modern science at the heart of Ecofeminism should be examined. Mies and Shiva articulate what may be seen as the 'classic' elaboration of a feminist standpoint 
epistemology (e.g., as in Merchant 1980) and one which is set explicitly in opposition to both empiricist and what they term 'feminist theory of difference' perspectives.

\section{Ecofeminism as a critique of scientific rationality}

[M]odern civilisation is based on a cosmology and anthropology that structurally dichotomizes reality, and hierarchically opposes the two parts to each = other: the one always considered superior, always thriving and progressing at the expense of the other. Thus, nature is subordinated to man; woman to man, consumption to production and the local to the global, and so on.

(Mies and Shiva, 1993:5)

The central axiom of Mies's and Shiva's critique is that modern science is grounded in the linked material relations of patriarchal violence, capitalism and colonialism and that capitalism and colonialism, themselves, constitute (forms of) patriarchal violence. More specifically, they posit firstly that science and scientific rationality are both the core constituents and the driving motors of capitalist accumulation. That is, they argue that progress in scientific terms underpins 'growth' in capitalist terms. Second, they posit that the violence of scientific epistemology and practice has historically been constituted through the violence of colonial relations between industrialized and 'underdeveloped' countries. The consequence of these linked relations, they argue, is that the destructive effects of science are felt most by women and children, particularly those living in the 'underdeveloped' South, and are reflected in the progressive destruction of 'nature'.

Most fundamentally, perhaps, the locus of these oppressions is seen to rest in the dualistic and reductionist nature of scientific thinking and in the simultaneous romanticization of what science destroys. Here, women and nature are constructed as the quintessential objects of men, male domination and scientific inquiry. Violence against nature, they argue, is intimately linked with violence against women in an objectifying scientific world-view premised upon supposed binary oppositions between man/woman; man/nature; north/south; industrial/indigenous; and organized around domination and capitalist accumulation. The scientific pursuit and production of universalized 'truth' is seen to be grounded in the exploitation of women, nature and the 'Third World'. At the same time, women, nature and indigenous 'Third World' peoples are romanticized objects of male (what Mies terms the 'White Man's') desire. At all of these levels then, scientific rationality is seen as intrinsically the rationality of violence, desire and domination. Further, it is understood as an essentially male rationality.

It is in and through their outline of what is axiomatically oppressive about science that Mies and Shiva posit ecofeminism as its obverse. 


\section{Critical contradictions: ecofeminism as standpoint}

In defying this patriarchy, we are loyal to future generations and to life and this planet itself. We have a deep and particular understanding of this both through our natures and our experience as women.

(Mies and Shiva, 1993: 14)

In a chapter entitled 'Feminist research: science, violence and responsibility', Mies lays out what she defines as the underpinning principles of feminist research generally and ecofeminist politics (including this book) more specifically. She begins with a set of 'methodological guidelines for feminist research'. Here, in somewhat prescriptive fashion, she offers as generic a definition of feminist research methodology that derives expressly from a critique of the principles of scientific method and epistemology. Scientific method, she argues, constitutes a mythology of 'value free', 'objective' research which is shored up by the enormous social power and currency of scientific expertise and which constitutes a driving motor of male domination. She argues the need to replace the scientific standpoint, which she terms the 'view from above' with the 'view from below', that is, the standpoint of those who are dominated. Referring to Freire's concept of 'conscientization', Mies posits the 'view from below' as the standpoint in which research that participates in a struggle against oppression (rather than in its reproduction) definitionally inheres. This standpoint, unlike science, is female, particularly 'indigenous', 'Third World' female. Thus, if science is the seat of false 'truth', the 'view from below' produces 'real' truth; if science is the epistemology of the status quo; the 'view from below' is the epistemology 'of the streets'.

In a somewhat more rigorously argued way than Mies, Shiva presents a similar analysis. For example, in her chapter 'Reductionism and regeneration: a crisis in science', Shiva counterposes the mechanistic and reductive nature of scientific reasoning with an 'organic' generative standpoint which she specifically associates with nonWestern, indigenous women. Here she argues that mechanistic 'metaphor[ic]' rationality has fragmented female bodies and nature and has progressively eroded biodiversity. She goes on, in a later chapter, to argue that diversity is the basis of women's work and politics and the organizing principle of non-Western pre-scientific communities.

These perspectives rely on a number of essentialist assertions. ${ }^{6}$ First is the monolithic construction of the enterprise of science. Mies, for example asserts in characteristic vein that:

The feminist critique of science - particularly after Chernobyl - has made it eminently clear that all current science and technology is quite fundamentally military science and technology and not just when it is applied in bombs and rockets. 
While clearly Mies intends to emphasize the extensive power of modern science, it is strikingly reductionist and totalizing to say that all current science is 'quite fundamentally military'. As many have argued, following Foucault, to posit science as a monolithically powerful enterprise not only misrecognizes the complexity of how power relations are lived out more broadly, but it also, paradoxically, underestimates how powerful science 'really' is. It seems more plausible that science is powerful precisely because its practices are contingent and its effects are partial rather than either being absolutely and categorically determined.

Moreover, as stated above, central to both Mies's and Shiva's treatment of the power of science as monolithic is their identification of it as quintessentially male. Indeed, underpinning their analyses is an absolute and reified notion of male identity and power. Mies, in particular, speaks of the male, the White Man, the 'famous male urge for omniscience and ominpotency [sic]' (1986:51, emphasis ours), counterpointed implicitly and, at times explicitly with a similarly abstracted and universalized notion of the oppressed woman. We would suggest that there is an important difference between arguing that science is gendered, or is patriarchal (in the sense that it is 'masculinized' or expressive of the social relations of male dominance), and asserting that it is essentially male and the product of an 'urge'. Indeed, the biological determinism of Mies's and Shiva's language seems a particularly ironic mode in which to critique the destructive (often biologically determinist) dualisms of science.

For both Mies and Shiva, the totalizing and reductionist construction of science and scientific power is counterpointed by an essentialized and romanticized construction of female consciousness and experience and of 'nature'. ${ }^{7}$ As a methodological principle, for instance, Mies posits that women (particularly indigenous women) and 'nature' are intrinsically interlinked as quintessential targets of scientific domination and as the loci of truth and (potential) conscientization. Not only does this formulation erase the considerable differentials of power, positionality and experience among women, but it also romanticizes 'the other' in terms which Mies later identifies as a characteristic component of scientific and colonial domination.

Shiva's version of this dualism revolves around her counterpoint of mechanistic versus 'organic' thinking. She cites the medicalization of childbirth, with its fragmentation and fetishization of the female body (Shiva, 1988:26), and biogenetic technologies, which 'convert nature into a ... genetic resource to be engineered, patented and owned for corporate profit' (28), as particularly poignant examples of the mechanistic logic of modern science. 'Formerly', she asserts (without specifying when 'formerly' refers to), 'the focus was on the mother and the organic unity of mother and baby' (26) and on the sacredness of soil (soil as 'sacred mother'); this alleged pre-scientific standpoint supposedly was in harmony with women and nature. The oppression of women and nature, Shiva asserts, began with Western scientific imperialism and, 
presumably ends with its repudiation; oppression is, apparently, an essentially modern invention.

This approach to nature which sees the soil as the mother and people as her offspring, not her master, was and is universally shared even though it has everywhere been sacrificed as representing only a narrow, parochial viewpoint and approach. In its place has been introduced the culture of the white man, universalized first through colonialism and then development, which sees the soil only in terms of territory to be conquered and owned.

(Shiva, 1993: 105)

Thus, as with Mies, the romanticized, essentialist link between women and nature versus male culture is presented here implicitly as the basis for an alternative to scientific rationality; between benign/true and destructive/false universalisms.

\section{Critical/questions}

Mies and Shiva are surely right to locate an analysis of science both in terms of oppressive power relations within and outside science, to develop a critical identification of the constituents of scientific epistemology and to make (or restate) links between scientific and colonialist politics and between science and oppressive social relations. However, as we have seen, their perspectives on science are characterized by a number of profound contradictions. Most disturbing perhaps is that it is exactly those elements they identify as the most damning indictments of modern science, i.e. dualism, reductionism, universalism and romanticism, which underpin Mies's and Shiva's own critique of science. Indeed, it is ironic that while both warn of the dangers of simply 'up-ending' the dualisms underpinning science (Mies and Shiva 1993:5), this self-same inversion is what seems to inform their definition of the source and character of the ecofeminist alternative.

Also significant in this context are Mies's and Shiva's insistence that their ecofeminism constitutes a materialist critique and politics. This underpins the stress made not only on capitalist accumulation and patriarchal violence but also on the exploitation (and oppression) of women and on women's resistance to these oppressive relations. Yet while both continually make reference to these relations, neither actually gets down to defining or tracing them as specific processes. This has the effect of essentializing capital, cash and patriarchy as disembodied/abstract agents with will, motive, feelings and drive. It also banalizes and elides (respectively) both the processes of oppression and the impetus for and character of protest. If one accepts (as one of us does) the standpoint that the dominant paradigm of science is fundamentally/ epistemically oppressive, is it not possible to develop such a critique through a recognition of and engagement with the highly diverse and contradictory theories and practices that constitute science rather than 
pretending that it is all the same thing? To refuse to be specific, or acknowledge partialities seems ultimately (and paradoxically) to deny, firstly, that science is socially constructed and, secondly, that feminists have any chance of changing the fundamental character of what we think of as science. It is, of course, for these reasons, among others, that some feminists have critiqued feminist standpoint approaches (or some versions of them)!

\section{Ecofeminism as neo-universalism?}

The contradictory character of Mies's and Shiva's critique of science is, perhaps, most acutely reflected in their proposal for an alternative epistemology which, as mentioned earlier, they counterpose both to traditional scientific universalism and to 'cultural relativist' perspectives which they identify with postmodernism and, specifically with 'the [sic] feminist theory of difference'.

Mies and Shiva begin by stating that they share certain elements of what they identify (in blanket fashion) as postmodern critiques of universalist (Western) ideologies. They state that they agree, for example, 'that the universalisation of modernization - the European project of the Enlightenment - has failed' (1993:11). Mies and Shiva posit that, spurred by the demise of European socialism, there has been a growing movement to deconstruct 'all universal ideologies based on a universal concept of human beings and their relation to nature and other human beings' and to critique 'the dualistic division between superstructure or culture and the economy or base' (11).

They argue, however, that this critique has given rise to 'cultural relativism' which they define as: (a) the focus on culture and difference at the expense of patriarchy and capitalism and at the expense of commonalities; and (b) the 'suspension of value judgement' with the consequence that patriarchal and violent practices are accepted as 'cultural expressions' of a particular people. Cultural relativism, they argue, destroys the basis for resistance and activism by denying the commonalities that characterize the 'view from below' and the universality of 'basic needs' for food, shelter, affection ... etc., 'which are common to all people irrespective of culture, ideology, race, political and economic system and class' (13). In other words, political resistance to scientific universalism necessarily has a universal base in (women's) common experiences of patriarchal and capitalist violence and in essential needs.

As with Mies's and Shiva's critique of scientific philosophy, their critique of cultural relativism, as its obverse, confusingly relies on a number of generalizations and odd elisions. While they rightly, in our view, identify relativist perspectives as fundamentally problematic, the terms in which they do so are also rather perplexing. For example, as noted above, they argue that relativism fails as an 'alternative to 
totalitarian and dogmatic ideological universalism' because it constitutes a 'suspension of value judgement' (12). This formulation implicitly locates 'proper' anti-Enlightenment critique in the realm of moral judgement rather than as an analysis of power. Indeed, we would suggest that the problem with cultural relativism is not a suspension of value judgement, but a focus on difference in the absence of an analysis of power relations (or, to paraphrase Catharine MacKinnon, the difference difference makes).

In this context, Mies and Shiva seem to suggest that to focus on cultural (and implicitly other forms of) difference is relativist per se. This includes what they term 'the [sic] feminist theory of difference'. A concentration on cultural differences is posited as a kind of intellectual indulgence ${ }^{8}$ which not only ignores the simultaneous fragmentation and homogenization of local cultures through international capitalism, but, indeed reaffirms these relations. They write:

Cultural relativism is not only unaware of these processes [of fragmentation and homogenization] but rather legitimizes them; the feminist theory of difference ignores the working of the capitalist world system and its power to transform life into saleable commodities and cash.

(1993: 12, emphasis ours)

This seems to suggest that all feminist theory which considers difference amounts to one theory and contributes, definitionally, to the agenda of 'liberalism which is rooted in colonialisation [and which] accords with the agendas of multinational corporations' (12). In other words, Mies and Shiva appear to assimilate into relativism any concern with or consideration of difference. In so doing, they implicitly dismiss precisely those bodies of feminist critique which have problematized the racist, heterosexist and classist (to name a few) assumptions of dominant white Western paradigms of feminist critique as well as of dominant social institutions and relations. Would they argue, for example, that Black feminist perspectives, which have specifically been concerned to analyse what Patricia Hill Collins (1990) terms the 'matrix' of oppressions, constitute cultural relativism?

Mies and Shiva propose that 'the way out of relativism' (12) is to be found in an alternative universalism which emerges from the allegedly intrinsic commonalities of grass-roots ecofeminist activism (the 'view from below') and which is orientated to 'real universal needs rather than abstract "rights"' (13). They write:

In dialogues with such grassroots women activists, cultural relativism does not enter. These women spell out clearly what unites women worldwide, and what unites men and women with the multiplicity of life forms in nature. The universalism that stems from their efforts to preserve their subsistence - their life base - is different from the Eurocentric universalism developed via the Enlightenment and the rise of 
patriarchy ... [The] fundamental needs for food, shelter, clothing; for affection, care and love; for dignity and identity; for knowledge and freedom, leisure and joy, are common to all people, irrespective of culture, ideology, race, political and economic system and class.

(1993: 13)

The ironies of Mies's and Shiva's proposal for an alternative universalism are grounded in two significant assumptions about the character of ontology and epistemology - i.e., that ontology is essential rather than contingent (there are intrinsic commonalities in women's experiences which override their differences); and that ontology equals epistemology (the knowledge of women emerges from/equates with the be-ing of women). Yet we would ask: is the way out of both cultural relativism and scientific universalism through a new universalism and an assertion of 'alternative' essentialisms or might it be better addressed through an analysis of power relations. And we would ask if the basis of unity and resistance is to be found not in a presumed ontological commonality (as women, as victims, as colonized) but rather in a shared political agenda which is developed through a range of standpoints which, as Bina Agarwal (1992) has argued, are situational, located in specific and complex material relations of space, place and power. Ultimately, Mies and Shiva argue, the answer to universalism is universalism, the answer to determinism is determinism. Moreover as with the 'old' universalism of science, it is difference, not power, which is problematized in Mies's and Shiva's 'new' universalism.

While Ecofeminism presents what may be a particularly striking example of these contradictions, nevertheless, the issue of how to develop a critique of scientific rationality which does not reproduce the assumptions underpinning it remains a vexed question. How, for example can we discuss power relations without making claims to 'truth'. Indeed, what else is a 'standpoint' but an attempt to identify a relationship (without necessarily making an equation) between ontology and epistemology? Does the project of developing feminist forms of materialist critique inevitably recuperate the core assumptions of modernity ${ }^{9}$ Finally, how in this context can we conceptualize differences and commonalities in ways which avoid the problems of both determinism and relativism? It would seem to us, that if an equation of ontology and epistemology constitutes a foundation for determinism, relativism emerges, at least in part, from seeing them as separate. ${ }^{10}$ The problem is not Mies's and Shiva's desire to acknowledge and hold on to common or related modes of oppression, experience and resistance among different groups of women, but rather their view of such commonalities in terms of transcendence. This is epitomized in their references to coming together despite our differences and in the positivist notion of an essential female consciousness. Ultimately, to equate ontology and epistemology, as Mies and Shiva do, seems to involve an erasure of precisely those power relations they seek to problematize in relation to science as well as in relation to relativism. 
As we shall see, the fundamental problems which characterize Mies's and Shiva's perspectives on science are extended to and through their perspectives on development, raising similar questions about the relationship between positionality and philosophy, critique and politics.

\section{Ecofeminism and the 'Colonies of White Man'}

Mies's and Shiva's critique of development is in terms which parallel their view of science, namely 'development' is essentially a Western concept, and realized as a colonizing project within power relations dominated by the West. ${ }^{11}$ Like science it embodies patriarchal assumptions and its masculinist logic is seen as radically opposed to what Shiva calls 'the feminine principle' under which 'nature', indigenous peoples and the 'Third World' are variously subsumed, along with a range of values and practices which are held to be in opposition to what Western/capitalist/patriarchal development stands for. If Western development is inherently destructive, it is ultimately Mother Earth, women and other embodiments of the 'feminine principle' which receive the full force of that destruction. The feminist kernel of eco-politics is provided by this identification of women with nature, an alliance which is both strategic and essential, since by defending nature against the patriarchal depredations of development, women are not only defending their livelihoods but womanhood itself.

Ecofeminism's theoretical approach to development is an adaptation of that elaborated in Patriarchy and Accumulation on a World Scale (1986). Here Mies produced a version of underdevelopment theory combining elements of the analyses of Samir Amin (1974), Gunder Frank $(1971,1978)$, Rosa Luxemburg (1913) and others, to argue that the concentration of science and technology in the core countries and the consequent international division of labour and unequal exchange between centre and periphery condemned the latter to progressive pauperization: 'the relationship between these overdeveloped centres or metropoles and the underdeveloped peripheries is a colonial one' (Mies, 1986:56). Moreover, 'Today, a similar colonial relationship exists between Man and Nature, between men and women, between urban and rural areas. We have called these the Colonies of White Man. In order to maintain such relationships force and violence are always essential' (56).

Mies's analysis of the world capitalist system thus locates women within the broader processes of Western capitalism and colonialism. Just as underdevelopment theory depends on surplus drain as its core explanatory principle, a process in which the advanced capitalist countries siphon off, for their own advantage, the surplus produced in the 'Third World', so women, too, have their surplus expropriated by men and by capital simultaneously, because the capitalist system is quintessentially patriarchal. The logic of capital is endless accumulation and from Luxemburg is derived the notion that capital depends 
for its survival on exploiting the natural economy. The natural economy is where women reside, both as subsistence producers in the Third World and as housewives in the advanced capitalist countries. The processes of capitalist development work to marginalize women but also to exploit their unpaid labour. Mies calls this the process of 'housewifisation'. ${ }^{12}$ She sums up this relationship between the capitalist West and women thus: 'women can therefore be called the internal colony of this system' (58).

Mies further identifies something she calls the 'myth of catching-up development' as a crucial ideological underpinning of the process of world accumulation. 'Catching-up' development, Mies argues, represents a kind of false consciousness on the part of its deluded supporters: it is an erroneous belief that development, defined in terms of Western models, is a good in itself and one that is universifiable. She posits, furthermore, that the 'Third World' is itself captivated both by the desire to replicate the 'success' of the West and by a blind faith in 'its' science, technology and market system. Affluent Westerners exhibit a 'collective schizophrenia' in relation to unlimited consumption: this reflects a misguided belief that high material living standards make for a good life. Instead, she says, the reality for the West is a meaningless life while for the colonies 'catching-up' development is 'a lost game'. She concludes that: the failure of 'catching-up' development to deliver this 'concrete Utopia' leads to frustration and despair, to waves of fundamentalism and nationalism, further destruction of the environment, further exploitation of the 'Third World', further violence against women and militarization of men (Mies, 1986: 64).

On the basis of this theory, a new eco-perspective is erected as the categories of economy and ideology give way to a different discourse, one which places 'nature' at its centre and, in classic opposition, counterposes it to culture. Shiva's concern, for example, is that the international processes of development cause a generalized human condition of 'uprootedness':

Development has violently severed the sacred bonds between the people and the soil, yet 'this approach to nature which sees the soil as the mother and people as her offspring, not her master, was and is universally shared even though it has everywhere been sacrificed.

(Shiva, 1989: 104)

Development and colonization, she argues, have led to the disappearance of the once-organic 'motherland' and there has occurred instead a masculinization of state and society in the service of the market. This discourse has much in common with nineteenth-century romanticism in its critique of modernity and industrialization and in its reinvocation of the themes of the loss of community. Shiva goes further in seeing the rise of nationalism and of inter-ethnic violence as responses not so much to the failure of catching-up development but to the loss of the fundamental links to the soil that this entails. Mies adds 
that these political phenomena legitimize the militarization of men and identification with the fatherland through projecting a yearning for lost motherlands on to nation-states.

This theme of yearning for what is lost (nature/rootedness authenticity) runs through the book. It is deployed to explain tourism - an activity engaged in by Westerners, depressed and alienated by urban living, but who also have the urge to return to nature - in a controlled way, while inevitably 'destroying what they yearn for'. Yearning for nature and grief for its loss is also expressed by men through women's bodies; pornography and 'sex tourism' are offered as examples of the connexion between male violence and desire, the latter expressive of colonial master-servant relations. Mies asks: 'Why do these men want women whom they otherwise do not respect? ... What, apart from the intoxication of power and dominance do these men want from those poor foreign, colonised women?' The answer lies not in specific cultural constructions of racism, but in the fact that modern men have little physical contact with nature unmediated by machines ... 'the more abstract becomes the relationship between man and nature, the more alienated man becomes from his own organic, mortal body', 'the sexual act has become virtually the only direct contact to nature available to the civilized man' (Mies and Shiva, 1993:137).

Thus, the more man appropriates and destroys women and nature the more he hungers for them. Once again, women and nature are the repositories of what is meaningful in the modern world. Moreover, there is an extraordinary implication here that male grief and alienation underpin, and render comprehensible, men's sexual violence against and exploitation of women. In this context Mies seems to argue a version of 'Oedipal conflict' which sees the crisis of modern manhood in terms of loss of sex/woman/nature and women's crisis as a loss of 'generative potency', i.e., motherhood/maternity. This dualistic equation of men with sex and women with reproduction is a classic cliche of dominant discourses of heterosexuality.

\section{Critical in-distinctions}

The theoretical foundations of Mies's and Shiva's critique of development are somewhat eclectic if not contradictory. A Marxist economic analysis has been grafted on to an idealization of some essential, universal human inclination which is offered as a principle of explanation of phenomena as diverse as tourism, nationalism and colonialism. What these two elements share however is an underlying essentialism, which while perhaps less obvious in Mies's account of the accumulation process is just as important to it as it is to the account of the natural world and its fascination for those alienated from it. It is to Mies's characterization of the economic system to which we will briefly turn.

There can be little doubt as to the dynamic force, destructive 
capacity and exploitative character of 'really existing' capitalism. The critique of 'growth for the sake of it' which Mies and Shiva share is certainly pertinent if hardly controversial even in less radical circles than those Mies and Shiva move in. But the breathless sweep of Ecofeminism's polemic is based on a theory of the world system which fails to convince. It is indeed surprising to find at its heart an uncritical reinvocation of underdevelopment theory after more than twenty years in which it has been criticized (from all quarters) for lacking explanatory power, for its simple dichotomies of core and periphery, and for having its stagnationist assumptions contradicted by the facts of postcolonial development. ${ }^{13}$ The very diversity of economic outcomes in the postcolonial world suggest at the very least that surplus drain, the theoretical basis of the idea that the Third World can never develop or 'catch up' with the West, has been shown to be an insufficient basis for understanding the more complex processes involved in development. Nor is it adequate to deal with the question of the relationship between a putative 'centre' and a homogenous 'periphery' as 'colonial' as if this suffices to explain all the very real (and very diverse) problems associated with 'Third World' development. In this approach 'Third World' social formations, with their distinctive histories, state and cultural forms, class formations, divergent policies and natural endowments, all become the same eternal victims of the depredations of the West. South Korea, Hong Kong and Brazil are no different really to Burundi, Timor or Yemen. ${ }^{14}$

Women's oppression too, is conceived of in parallel terms, their unpaid work is both central to the accumulation process, and their sexuality and otherness acts to compensate modern men for their alienation from nature. Yet this whole account depends upon an idyllic reinvocation of pre-Enlightenment, pre-colonial, and pre-modern cultures which were supposedly based on the 'feminine principle' and on a natural order conceived of as essentially good. Such knowledge systems as existed, we are told, were expressive of a respect for nature, were often woman-centred and woman-friendly. Shiva even goes so far as to talk of pre-modern contraceptive techniques on this basis, calling for a return to these knowledges. Here again, a complex history is rendered universal and homogeneous; what occurs in this account is a simple inversion of the paradigm of civilization being achieved through the domination of nature which results in an equally crude romanticization of something imagined as 'traditional nature-based society', one which is free from male dominance and conflict, a pre-oedipal place of maternal nurturance. The reality of such societies and knowledge systems was often far more diverse than this picture allows and certainly, in many cases, rather far from this ideal type. While we would not dispute the validity of the project of reclaiming particular knowledges and practices by women and by some indigenous peoples, that have been erased, this process of recuperation must be based on an analytic engagement with the complexities of these histories rather than on an assertive idealization of 'ancient wisdoms'. 'Old' knowledges, after all, were historically and politically constituted in often very contradictory ways. 
In sum, despite the appearance in recent decades of a rich source of information and debate, and a plethora of feminist writings on the issues discussed in this book, what it re-presents is a determinist, structuralist and ahistorical account of processes which are far more varied, complex and contingent. Indeed it could be argued again that Mies and Shiva reproduce precisely the reductionism which they themselves criticize in relation to science. This oversimplified account of the process and necessary effects of capitalist development also endows capitalism and the capitalist system with autonomous motives and agency; it too becomes a power monolith but, as with science, the actual relations and practices through which power is expressed and mediated are never explicated. Again, as with science, there is a metaphorical reference to violence, colonialism and patriarchy which implies material relations but does not ground the analysis in anything other than an expressive totality. Everything is the same as everything, everything expresses the same thing.

The idealization of a necessary linkage between women and nature further operates to obstruct analysis of the ways in which women are differentially situated in relation to their environment and to environmental issues more generally. There is surely nothing given in this relationship, one which is contingent on a variety of social factors, not least among them class and social relations. The fact that many poor peasant women depend for their livelihood on preserving trees or brushwood tells us more about the social relations within which they live than about the essential character of women. ${ }^{15}$ As Jackson (1993) points out, we have to ask why women have come to be defenders of trees, and whether identifications of the woman-nature variety have more to do with the processes through which women become socially marginalized through the operations of the sexual division of labour and indeed of patriarchal power. Mies and Shiva simply never discuss how relations between the sexes are constituted and what specific ways these power relations might underpin women's 'special' relationship with 'nature'.

This failure to address the question of power relations between men and women relates to what seems a more general assumption (and idealization) of heterosexuality underpinn'' ' while Mies and Shiva repeatedly refer to the rather reified notion of 'man-woman' relationship problems and to patriarchal violence, neither considers the specific social relations of men's violence with respect to women. This is a striking absence in the discussion of fertility control, where it is assumed that the issue for women is one of re-appropriating traditional knowledges as if this were a matter of choice, whereas it is women's capacity to exercise choice at all which is often in question. Mies's description (discussed earlier) of sexual intercourse as (ideally) a celebration of nature seems to posit ecofeminism as a standpoint which is intrinsically and necessarily heterosexual. ${ }^{16}$ That is, the characteristic equation of nature not only with women but with heterosexuality carries the unfortunate implication that rescuing heterosexuality is central to the rescue of both 'nature' and women. ${ }^{17}$ 
This bias in Ecofeminism is shored up by Mies's and Shiva's continual romanticization of mothers and motherhood as characterized by an inherently radical consciousness. For example, in Mies's chapter 'Who made nature our enemy' on the lessons to be learned from Chernobyl, she writes:

\begin{abstract}
What purpose can be served by writing about [Chernobyl] now? Should we not rather emulate those feminists who say: 'We are not responsible for this destructive technology. We do not want it. Let those men, or those patriarchs who are so enthusiastic about their technological dominance over nature now clear up the mess. We are fed up with being the worlds' housewives.' This reaction is understandable, but does it help us? Women don't live on an island; there is no longer any place to which we can flee. Some women may feel that it is better to forget what happened at Chernobyl and enjoy life as long as it lasts since we must all die eventually. But women with small children cannot afford this nihilistic attitude.
\end{abstract}

(1993: 91, emphasis ours)

In suggesting that there are good eco-minded mothers and 'nihilistic' and childless feminists Mies reinvokes a rather tired stereotype which impugns both 'egoistic' feminists and lesbians. ${ }^{18}$ The consequence of those formulations is the implication that the ecofeminist standpoint proposed by Mies and Shiva finds its impetus in (heterosexual) motherhood and its resolution in the repudiation of a patriarchal science which destroys not only mothers but Mother as icon and object of reverence. ${ }^{19}$ However, in the absence of an analysis of the complex power relations of and social conditions surrounding women's experiences of mothering, Mies and Shiva seem to recuperate rather than challenge conventional heterosexist iconographies of Motherhood. While the heterosexist undertone of Ecofeminism may not have been intended, it is certainly problematic that in a book that is, in part, concerned to critique male violence with respect to reproduction, reproductive technologies and population control policies and to consider these in relation to the politics and philosophies of modernity and development, there is a pointed absence of an analysis of the relationship between compulsory heterosexuality, gender and the other forms of oppression acknowledged in the book.

\title{
Back to the future?
}

The common ground for women's liberation and the preservation of life on earth is to be found in the activities of those women who have become the victims of the development process and who struggle to conserve their subsistence base. 
Given the various elements which make up the theoretical approach of Ecofeminism, it is hardly surprising that the vision it holds out as inspiration for the future is one which is based on a return to nature and to a society based not on accumulation/growth but on production for subsistence. The governing principles of this society are participatory democracy, 'de-linking' from the world economy and 'ethical decolonisation', this latter concept inspired by Shiva's extraordinary claim that 'most non-Western cultures have been based on the democracy of all life' (Shiva, 1989: 265). ${ }^{20}$

Once again a simple inversion is deployed in which real problems are wished away in favour of a series of clichés. ${ }^{21}$ The ecofeminist Utopia is one where there is no capitalism, no market, no state, no poverty, no science and no patriarchy (yet is still heterosexual). Whatever the attractions of some of these super-ordinate goals, the routes of transformation surely cannot come from a recovery of an imaginary past. Mies and Shiva assume that because subsistence economies are quintessentially 'non-modern' they must 'therefore' be non-oppressive, hence there is no need for states, laws or for regulation; all will be achieved through co-operation and grass-roots participation. Quite how upwards of 6 billion people will manage to survive on the basis of subsistence production does not detain the authors of Ecofeminism, any more than such difficult questions as how we might reach this Utopian state do. Again, Mies and Shiva refrain from both acknowledging complexities and engaging in substantive consideration of social relations and processes of survival and democratization.

In the meantime how does this vision inform the feminist agenda for political action in the present? The answer is given in grass-roots activism to preserve the environment, what Mies describes as the essence of 'the subsistence perspective'. While all women have an interest in defending the environment, none the less some women have a privileged role in the struggle:

The common ground for women's liberation and the preservation of life on earth is to be found in the activities of those women who have become the victims of the development process and who struggle to conserve their subsistence base.

(Mies and Shiva, 1993: 12)

The Chipko movement of Uttar Pradesh is seen as a paradigm of ecofeminism in action, combining as it does 'grass-roots' struggles, by women apparently directed at preserving nature because it is upon nature that they depend for survival. ${ }^{22}$ Yet, how far can struggles waged by poor women (whose livelihoods are directly threatened by environmental degradation) serve as a model for ecofeminist politics in general? Surely 'defending women's place as subsistence producers' is a rather limited goal and one which does not problematize gender relations at all? ${ }^{23}$ And do grass-roots struggles constitute the one possible form of ecofeminist practice? 
Besides this abstract treatment of activism, there are occasions when they are more concretely programmatic, such as in the proposals for forming urban collectives and practising what amounts to green consumerism. Yet it is surprising that having constructed a monolithic and over-determining model of systemic oppression, they imagine this can be challenged through opting out on the one hand and through alternative consumption patterns, on the other. The latter proposal embraces the ethos of 'voluntary simplicity' (Mies, 1986:251) by which is meant a 'voluntary reduction in the living standards and a change of consumer patterns by the rich countries and classes' (253). Mies calls for 'consumer liberation', whereby all rich consumers suddenly see the light and become ecologically conscious (which means restricting consumption). The implications for the 'housewifised' are clearly significant since what this proposal will in all likelihood involve is an intensification of their unpaid labour to substitute for environmentally unsound commodities. It is clear that the gender relations of consumption are not challenged by green consumerism alone (or even at all); if anything women acquire even more responsibility in this domain. Moreover, this attribution of power to consumers is striking for its liberal and individualized vision of change and also seems at variance with their own analysis of how patriarchal capitalism works.

\section{Conclusion}

We began this review by recognizing the promise of Mies's and Shiva's project in Ecofeminism. In particular, it suggests the need to understand modern science, colonialism and development as interrelated processes. This is an important perspective for those working in the fields of feminist critiques of science and/or of development. However as is evident from the above, this promise remains unfulfilled. Ecofeminism is a patchwork of themes and insights many of which raise pertinent issues. But the underlying theoretical assumptions are deeply flawed and have the unintentional effect of depoliticizing the agenda of environmental feminism first by displacing the analysis of specific historically and socially constituted gender relations by a timeless and universal set of dichotomies of which the women/nature example is primary. This reduces feminist politics - including questions of strategy - to something given in the nature of women. Secondly, the assumptions underpinning Mies's and Shiva's Ecofeminism render it incapable of generating a politics adequate to the enormity of the threat to survival presented by environmental degradation. This is in part because Mies and Shiva rehabilitate and indeed celebrate the public/private split of classical philosophy in order to argue that the only meaningful politics for women is outside the sphere of male power, in women-centred spontaneous grass-roots struggles. ${ }^{24}$ This not only operates with a reductionist extrapolation of what a feminist politics is but in leaving 
the central assumption of a dualistic arena for politics intact, Ecofeminism fails to engage with the problem of how political power is organized, let alone offer a real challenge to it.

\section{Notes}

Maxine Molyneux teaches political sociology at the Institute of Latin American Studies, University of London; Deborah Lynn Steinberg teaches feminist studies in the Department of Sociology, University of Warwick, England.

1 We would like to thank Bina Agarwal for her comments on an earlier draft of this article.

2 In an important article on ecofeminism, and critique of Shiva, Agarwal (1992) has analysed the different feminist positions which have emerged in relation to science. She has also examined the ways in which the woman/ nature link is constituted within ecofeminist discourse.

3 See, for example, Alic (1986); Harding (1986); and Kirkup and Smith Keller (1992).

4 This critique of feminist standpoint approaches specifically the contention that female ontology provides a quintessential basis for a critique of science as a male enterprise; hence the notion of a 'woman's standpoint'. However, not all standpoint theorists accept the essentialism implicit in this formulation, nor utilize a homogenous concept of 'woman' in their formulation of a critique of the normative practices and philosophies of science (see, for example, Harding 1991).

5 Mies and Shiva tend to use the generic 'South' in preference to 'Third World'. However both terms suggest a unity, similarity and 'otherness' with respect to the First World/North - none of which can automatically be assumed. We use the term Third World therefore with considerable reservations.

6 By 'essentialism' we refer to perspectives which construct social processes/ patterns in ways which suggest that they are fixed (often biologically fixed), immutable and inevitable. Essentialist approaches are associated with deterministic theories such as sociobiology and versions of structuralism. Feminism has been notable for critiquing biological (and social) determinist theories. However, many feminists have also pointed out that there are contexts in which it may be necessary (or unavoidable) to use a considered essentialism in order to formulate perspectives which challenge common senses. Epstein (1993), among others, argues that the use of racialized categories or identifications, for example, can be a necessary (though problematic) essentialism in anti-racist struggle. See also Lovibond (1992).

7 Although it is constantly invoked, neither Mies nor Shiva define what they mean by 'nature'.

8 They write:

While intellectuals may concentrate on culture and on differences, international capital continues with its expansion of production and markets, insisting on free access to all natural resources and life forms and to localized cultures and traditions and their commodification.

(Mies and Shiva, 1993: 12)

The implication here is that examination of culture and difference is fundamentally at odds with a materialist critique. 
9 It can be argued, in this context, that while classic feminist standpoint critiques of science may be legitimately critiqued for reproducing certain key essentialisms characteristic of science (e.g., in the notion of a unified female subject), it is not necessary (or possible) to abandon any claim to materially and positionally grounded analysis (see Harding, 1991).

10 The separation of knowledge from be-ing in this sense relates to the separation of public and private as a bedrock of classic liberal thought.

11 There are no significant differences between state socialism and capitalism as far as this approach is concerned.

12 For further discussion of the concept of 'housewifisation' see Mies, Benholdt-Thomsen and von Werlhof (1988).

13 For a critical resumé of this discussion, see, for example, Brewer (1980).

14 The divisions within the North and South are as important as those between them. Moreover, as Guha (cited in Jackson, 1993) argues, the construction of the South as a place of spiritual and ecological awareness is a form of orientalism whereby agency and rationality are then dichotomously seen as the preserve of the West.

15 Agarwal distinguishes ecofeminism from what she terms 'feminist environmentalism', an approach which is characterized by its analysis of the social relations within which women and men are inscribed in order to contextualise their different dependencies on particular resources. (This approach is also sometimes known as the Gender, Environment, Development approach). See, for example, Leach, 1991; Agarwal 1992; and Jackson 1993.

16 Heterosexuality emerges in this context as a rather reified and static construct.

17 Indeed, Ecofeminism seems to suggest that along with the 'Third World' and women, capitalism has also 'underdeveloped' heterosexuality. This notion comes through with particular force in Mies's chapter 'White man's dilemma', discussed earlier, where she argues that alienation from nature, which she sees as characteristic of modern industrial life, underpins men's sexual tourism and women's investment in destructive reproductive technologies. The implicit heterosexism of this formulation has implications for Mies and Shiva's later proposal for a 'subsistence perspective' as an antidote to the destructive character and products of modernity. In the absence of some close consideration of the relationship between patriarchal social relations and institutionalized heterosexuality, heterosexuality (restored to its 'natural' pre-modern form) seems to emerge as a subsistence principle and a site of potential resistance against oppression.

18 We would suggest that this formulation and the idealization of mothers more generally also ignores the power relations of and social conditions surrounding motherhood. The construction of a motherhood as an exalted state of political consciousness seems not far removed from iconographies of mother/Madonna as repository of spiritual virtue.

19 Mies and Shiva posit mothers and motherhood as a particular target of the destructive practices of science and of development at several levels including: (a) that mothers and their children are particularly undermined by the toxic products of modern industrial and technological 'progress'; (b) that loss of motherland and of attendant reverence for motherhood and fertility is the paradigmatic feature of Western modernity; and (c) that the processes of patriarchal science and development have appropriated and undermined women's reproductive autonomy and health. 
20 Bina Agarwal (1992), (among others), has critiqued the premise, which underpins Shiva's earlier work, that all oppression emanates from the West.

21 For example: Mies's contention that affluence does not produce 'the good life' (money doesn't make you happy); that we need to recover the 'premodern'/pre-oppressive' (back to basics) and that affluent countries should 'reduce' their levels of consumption ('just say no').

22 There is considerable debate over how to interpret the significance of the Chipko movements. Guha, for example sees it as a defence of a conservative moral economy. See Jackson's discussion of this (1993).

23 Jackson (1993) notes that environmental protection and conservation are not necessarily woman-friendly in themselves.

24 Pateman (1989) describes the fraternal social contract, for example, as being premised on a division between 'civil society or the universal sphere of freedom, equality, individualism, reason, contract and impartial law' the realm of men . . ' and the private world of particularity, natural subjection, ties of blood, emotion, love and sexual passion - the world of women' in which she adds . . . 'men also rule' (Pateman, 1989: 43, emphasis ours).

\section{References}

AGARWAL, B. (1992) 'The gender and environment debate: lessons from India' Feminist Studies 18(1) Spring.

ALIC, M. (1986) Hypatia's Heritage: a History of Women in Science from Antiquity to the Late Nineteenth Century London: Women's Press.

AMIN, S. (1974) Accumulation on a World Scale New York: Monthly Review Press.

BREWER, A. (1980) Marxist Theories of Imperialism London: Routledge \& Kegan Paul.

COLLINS, Patricia Hill (1990) Black Feminist Thought: Knowledge, Consciousness and the Politics of Empowerment London: Harper-Collins.

EPSTEIN, D. (1993) Changing Classroom Cultures: AntiRacism, Politics and Schools Stoke-on-Trent: Trentham.

FRANK, A. G. (1967) Capitalism and Underdevelopment in Latin America New York: Monthly Review Press.

- (1978) World Accumulation 1492-1789 New York: Monthly Review Press.

HARAWAY, D. (1989) Primate Visions: Gender, Race and Nature in the World of Modern Science New York: Routledge.

HARDING, S. (1986) The Science Question in Feminism London: Open University Press.

- (1991) Whose Science? Whose Knowledge? London: Open University Press. (1992) 'How the women's movement benefits science: two views' in KIRKUP, G. and SMITH KELLER, L.

JACKSON, C. (1993) 'Environmentalisms and gender interests in the Third World' Development and Change Vol. 24, London, Newbury Park and New Delhi: Sage: 649-77.

KIRKUP, G. and SMITH KELLER, L. (1992) editors, Inventing Women: Science, Technology and Gender, London: Polity.

LEACH, M. (1991) 'Locating gendered experience: an anthropologist's view from a Sierra Leonean village' IDS Bulletin Vol. 22, No. 1, January. 
LOVIBOND, s. (1989) 'Feminism and postmodernism' New Left Review 178 (special issue on Defending Enlightenment): 5-28. (1992) 'Rorti and feminism' New Left Review No. 193, January.

LUXEMBURG, R. (1963) The Accumulation of Capital London: Routledge \& Kegan Paul.

MERCHANT, C. (1980) The Death of Nature: Women, Ecology and the Scientific Revolution New York: Harper \& Row.

MIES, M. (1986) Patriarchy and Accumulation on a World Scale London: Zed Press.

MIES, M., BENHOLDT-THOMSEN, V. and VON WERLHOF, C. (1988) Women: the Last Colony London: Zed.

MIES, M. and SHIVA, V. (1993) Ecofeminism London: Zed Press.

PATEMan, C. (1989) The Sexual Contract London: Polity Press.

SHIVA, v. (1989) Staying Alive London: Zed Press. 